\title{
HLA B27 antigen in Middle Eastern and Arab countries: systematic review of the strength of association with axial spondyloarthritis and methodological gaps
}

Nelly Raymond Ziade ${ }^{1,2,3}$

\begin{abstract}
Background: Axial spondyloarthritis (AxSpA) is a relatively frequent and debilitating disease, with a prevalence ranging from 0.1 to $2 \%$ in the Caucasian population. Current Assessment of Spondyloarthritis International Society (ASAS) classification criteria of AxSpA rely either on sacroiliitis on imaging plus one SpA feature or positive HLAB27 antigen plus two SpA features, in a patient with chronic low back pain and age at onset of less than 45 years. Therefore, HLA-B27 is a central feature in SpA classification and plays a pivotal role in referral strategies and early diagnosis. The primary objective of the study is to review the prevalence of HLA-B27 in normal and AxSpA populations in Middle Eastern and Arab Countries and to assess the strength of association between HLA-B27 antigen and AxSpA. The secondary objective is to identify the gaps in the methodology of the studies and suggest a framework for future research.

Methods: Studies were included in the analysis if they reported prevalence of HLA-B27 in AxSpA and/or general population and if they covered geographical location in the Middle East or Arab countries in the Mediterranean basin. Odds ratios (OR) were calculated for each country, as a measure of the strength of association between HLA-B27 and AxSpA, compared to the normal population, using the two-by-two frequency table. Available data from the literature were analyzed according to the following quality indicators: sample size, method of HLA-B27 testing, presence of control group and external validity.
\end{abstract}

Results: Twenty-seven studies were analyzed. HLAB27 prevalence in the normal population ranged from 0.3\% (Oman) to 6.8\% (Turkey). HLA-B27 prevalence in AxSpA ranged from 26.2\% (Lebanon) to 91\% (Turkey). HLA-B27 prevalence in all SpA ranged from 13.87\% (Lebanon) to 69.43\% (Kuwait). Peripheral SpA was less associated with HLA-B27 than AxSpA, indicating the need of differentiating between the two entities when calculating prevalence. When available (8 studies), the OR ranged from 21.63 (Morocco) to 105.6 (Syria). The high heterogeneity between the results can be due to differences in methodology: study sample size, different classification criteria, absence of control groups, HLA-B27 testing method.

Conclusions: The prevalence of HLA-B27 in the normal population is significantly lower in the Middle Eastern and Arab countries than in Western Countries. However, HLA-B27 testing can be useful for AxSpA positive diagnosis, given the high OR. Heterogeneity between countries may be due to methodological differences.

Correspondence: nellziade@yahoo.fr

${ }^{1}$ Rheumatology Department, Saint-Joseph University, Beirut, Lebanon

${ }^{2}$ Rheumatology Department, Hotel-Dieu de France Hospital, Beirut, Lebanon

Full list of author information is available at the end of the article

(c) The Author(s). 2017 Open Access This article is distributed under the terms of the Creative Commons Attribution 4.0 International License (http://creativecommons.org/licenses/by/4.0/), which permits unrestricted use, distribution, and reproduction in any medium, provided you give appropriate credit to the original author(s) and the source, provide a link to the Creative Commons license, and indicate if changes were made. The Creative Commons Public Domain Dedication waiver (http://creativecommons.org/publicdomain/zero/1.0/) applies to the data made available in this article, unless otherwise stated. 


\section{Background}

Axial spondyloarthritis (AxSpA) is a relatively frequent disease, with a prevalence ranging from 0.1 to $2 \%$ in the Caucasian population. It affects mainly young adults and can be significantly disabling with serious professional impact and high socioeconomic cost [1, 2]. Although AxSpA is a chronic disease evolving over several decades, recent evidence shows that early diagnosis and treatment may lead to better outcome [3]. Over the years, many classification systems were used to diagnose and classify spondyloarthritis [4-6], aiming, in the most recent Assessment of Spondyloarthritis International Society (ASAS) classification criteria, to reach earlier diagnosis [7]. The current ASAS classification of AxSpA relies either on sacroiliitis on imaging plus one SpA feature (imaging arm) or HLA-B27 antigen plus two SpA features (clinical arm), in a patient with chronic low back pain and age at onset of less than 45 years [8]. Therefore, HLA-B27 plays a central role in SpA classification and can be pivotal in referral strategies and early diagnosis [9, 10]. The association of axial SpA with HLA-B27 seems to be lower in most Arab populations compared to Western European populations [11], possibly due to genetic backgrounds. This may affect the diagnostic value of HLA-B27 antigen, and impact the local application of published referral strategies, which were studied in Western populations with high HLAB27 prevalence [9]. However, the heterogeneity in HLAB27 prevalence within Middle Eastern and Arab Countries [12] can be related either to true differences between the populations or to heterogeneity in the methodology of the studies. This heterogeneity may lead to errors in the estimation of the disease prevalence and delay in diagnosis. Previous studies reviewed the prevalence of HLA-B27 antigen in SpA and in the general population [11], but the strength of association was not numerically assessed regardless of the prevalence. The primary objective of the study is to review the prevalence of HLA-B27 in normal and AxSpA population in Middle Eastern and Arab Countries and to assess the strength of association between the HLA-B27 antigen and AxSpA in different populations. The secondary objective is to identify the gaps in the methodology of the studies and suggest a framework for future research.

\section{Methods}

A literature review on PubMed from beginning until nowadays was performed, using the following $\mathrm{MeSH}$ terms: HLA-B27 antigen, prevalence, ankylosing spondyloarthritis, spondyloarthritis, Middle East, Arab countries, in parallel with cross-reference search. Inclusion criteria were: studies evaluating the prevalence of HLAB27 antigen (regardless of the subtype) in AxSpA and/or the general population, inclusion of $\mathrm{SpA}$ groups according to any of the contemporary diagnostic criteria [New York (NY), Amor, ESSG, ASAS] and geographical situation in the Middle East as well as other Arab countries of the Mediterranean basin. Data were extracted from the Internet and pertinent information from the articles were recorded in a table following pre-specified criteria. For each study, the prevalence of HLA-B27, the country, the study sample size, and the type of population were reported. For SpA, the criteria type was reported, and the type (general population, other rheumatic diseases or blood donors) was recorded for the controls. Then, the strength of association between HLAB27 antigen and spondyloarthritis was assessed using the odds ratio [OR]. The OR represents the odds that an outcome (SpA) will occur given a particular exposure (HLA-B27), compared to the odds of the outcome occurring in the absence of that exposure. ORs are most commonly used in case-control studies; however, they can also be used in cross-sectional studies similarly to those included in this review. When available, the number of exposed $(a+b)$ and non-exposed $(c+d)$ were extracted from the studies and computed in a two-by-two frequency table against the disease status [SpA $(a+c)$ and controls $(b+d)]$. The OR is calculated using the classic formula: $a * d / b * c$ [13]. Values greater than one indicate a positive association between HLA-B27 and Spa; higher ORs indicate a stronger association. 95\% confidence intervals [CIs] were calculated for each OR when available. Furthermore, available studies were analyzed according to the following quality indicators: sample size, method of HLA-B27 testing, presence of control group and external validity. A Forest plot was constructed for ORs and 95\%CIs to visually assess their heterogeneity. Statistical analysis was performed using the MedCalc software, version 17.4.

\section{Results}

Twenty-seven studies, published between 1978 and 2012, were analyzed. All studies corresponding to the pre-specified eligibility criteria were included in the review. High heterogeneity was found between prevalence rates in the different studies. HLA-B27 prevalence in the normal population ranged from $0.3 \%$ (Oman) to $6.8 \%$ (Turkey). HLAB27 prevalence in AxSpA ranged from 26.2\% (Lebanon) to 91\% (Turkey). HLA-B27 prevalence in peripheral $\mathrm{SpA}$ ranged from $13.87 \%$ (Lebanon) to 69.43\% (Kuwait). Similarly to international studies, peripheral SpA was less associated with HLA B27 than AxSpA, indicating the need of differentiating between the two clinical entities when calculating prevalence (Table 1). More than two-thirds of the studies had no control groups; therefore, the measure of the strength of association was not possible in all countries, and the true diagnostic properties could not be assessed. When 
Table 1 Summary of the studies on HLA-B27 antigen prevalence in SpA and the normal population in Middle Eastern and Arab Countries

\begin{tabular}{|c|c|c|c|c|c|c|c|}
\hline Country & Sample Size SpA & $\begin{array}{l}\text { Sample Size } \\
\text { (Control) }\end{array}$ & $\begin{array}{c}\text { Prevalence in } \\
\text { Population }\end{array}$ & $\begin{array}{l}\text { Prevalence } \\
\text { in SpA }\end{array}$ & $\begin{array}{c}\text { Prevalence } \\
\text { in AS }\end{array}$ & $\begin{array}{l}\text { OR AS/GP } \\
{[95 \% \mathrm{CI}]}\end{array}$ & Reference \\
\hline Algeria & 129 AS (ESSG and NY) & $\begin{array}{l}76 \text { healthy } \\
\text { blood donors }\end{array}$ & $4 \%$ & & $69 \%$ & $\begin{array}{c}54.14 \\
{[16.09-182.18]}\end{array}$ & [17] \\
\hline Egypt & & $\begin{array}{l}380 \text { normal } \\
\text { individuals }\end{array}$ & $4.7 \%$ & & & & [18] \\
\hline Egypt & $\begin{array}{l}75 \mathrm{SpA} \text { (ESSG) } \\
\text { including } 34 \mathrm{AS}\end{array}$ & & & $58.7 \%$ & & & [19] \\
\hline Egypt & & $\begin{array}{l}100 \text { healthy } \\
\text { controls }\end{array}$ & $1 \%$ & & & & [20] \\
\hline Iraq & $25 \mathrm{AS}$ & & $2.1 \%$ & & $84 \%$ & & [21] \\
\hline Iran & $60 \mathrm{AS}$ & $\begin{array}{l}430 \text { healthy } \\
\text { blood donors }\end{array}$ & $3.95 \%$ & & $66.67 \%$ & $\begin{array}{c}48.59 \\
{[23.57-100.17]}\end{array}$ & [22] \\
\hline Iran & 119 AS & & & & $68.91 \%$ & & [23] \\
\hline Iran & 98 AS (NY) & & & & $73.4 \%$ & & [24] \\
\hline Israel & $38 \mathrm{AS}$ & $\begin{array}{l}456 \text { normal } \\
\text { individuals }\end{array}$ & $3 \%$ & & $79 \%$ & & [25] \\
\hline Jordan & $22 \mathrm{AS}(\mathrm{NY})$ & & & & $75 \%$ & & {$[26]$} \\
\hline Jordan / Qatar & 129 AS & 2579 healthy individuals & $2.4 \%$ & & $72.22 \%$ & $\begin{array}{c}104.87 \\
{[66.21-166.11]}\end{array}$ & [12] \\
\hline Kuwait & $58 \mathrm{SpA}(27 \mathrm{AS})$ & & & $69.43 \%$ & $82.56 \%$ & & {$[27]$} \\
\hline Kuwait & $35 \mathrm{SpA}+\mathrm{AS}$ patients & 544 controls & $4 \%$ & $25.7 \%$ & & $\begin{array}{c}8.21 \\
{[3.44-19.60]}\end{array}$ & [28] \\
\hline Lebanon & $\begin{array}{c}105 \mathrm{SpA} \text { (ESSG) } \\
24 \mathrm{AS}(\mathrm{NY})\end{array}$ & $\begin{array}{l}841 \text { Rheumatolgy } \\
\text { patients }\end{array}$ & $1.44 \%$ & $13.85 \%$ & $26.32 \%$ & $\begin{array}{c}24.46 \\
{[7.78-68.19]}\end{array}$ & [29] \\
\hline Morocco & $46 \mathrm{AS}+$ coxitis & $\begin{array}{l}183 \text { healthy } \\
\text { controls }\end{array}$ & $6.16 \%$ & & $58.70 \%$ & $\begin{array}{c}22.09 \\
{[9.48-51.49]}\end{array}$ & {$[30]$} \\
\hline Morocco & $49 \mathrm{SpA}$ (Amor and ESSG) & & & & $67 \%$ & & {$[31]$} \\
\hline Oman & & 321 healthy & $0.3 \%$ & & & & [32] \\
\hline Qatar & 119 AS (NY) & & & & $74 \%$ & & {$[33]$} \\
\hline Saudi Arabia & $12 \mathrm{AS}$ & & & & $66.67 \%$ & & [34] \\
\hline Syria & 50 AS (NY) & $\begin{array}{l}217 \text { healthy } \\
\text { controls }\end{array}$ & $1.4 \%$ & & $60 \%$ & $\begin{array}{c}105.64 \\
{[29.98-381.87]}\end{array}$ & {$[35]$} \\
\hline Tunisia & $365 \mathrm{AS}$ and/or BD & 124 controls & $3.2 \%$ & & $42.9 \%$ & & {$[36]$} \\
\hline Tunisia & 100 AS (NY) & $\begin{array}{l}100 \text { healthy } \\
\text { controls }\end{array}$ & $3 \%$ & & $62 \%$ & $\begin{array}{c}52.75 \\
{[15.61-178.31]}\end{array}$ & {$[37]$} \\
\hline Tunisia & 50 AS (Amor / ESSG) & & & & $69 \%$ & & [38] \\
\hline Turkey & 112 AS (NY) & 55 controls & $2.8-6.8 \%$ & & $70 \%$ & $\begin{array}{c}29.82 \\
{[9.99-89.05]}\end{array}$ & [39] \\
\hline Turkey & 216 AS (67 analyzed) & & & & $91 \%$ & & [40] \\
\hline UAE & & 760 healthy & $6.4 \%$ & & & & [41] \\
\hline UAE & $17 \mathrm{AS}$ & & & & $56 \%$ & & [42] \\
\hline
\end{tabular}

AS Ankylosing Spondylitis, BD Behcet's disease, Cl Confidence Interval, ESSG European Spondyloarthropathy Study Group analysis, GP General Population, NY New York criteria, OR Odds Ratio, SpA Spondyloarthritis

available (8 studies), the OR (HLA-B27 in AxSpA compared to HLA-B27 in the normal population) ranged from 21.63 (Morocco) to 105.6 (Syria). ORs are presented in Fig. 1, with their respective 95\%CIs. This Forest plot indicates large CIs and heterogeneity between the studies, although all ORs were largely greater than 1 .
Only 11 studies had both AxSpA and control groups. About one-third of the studies had a very low sample size (8 out of 22 AS studies had less than 30 included patients). The method of HLA-B27 testing was not included in the final quality assessment since it could not be identified in most of the studies. Clear and 


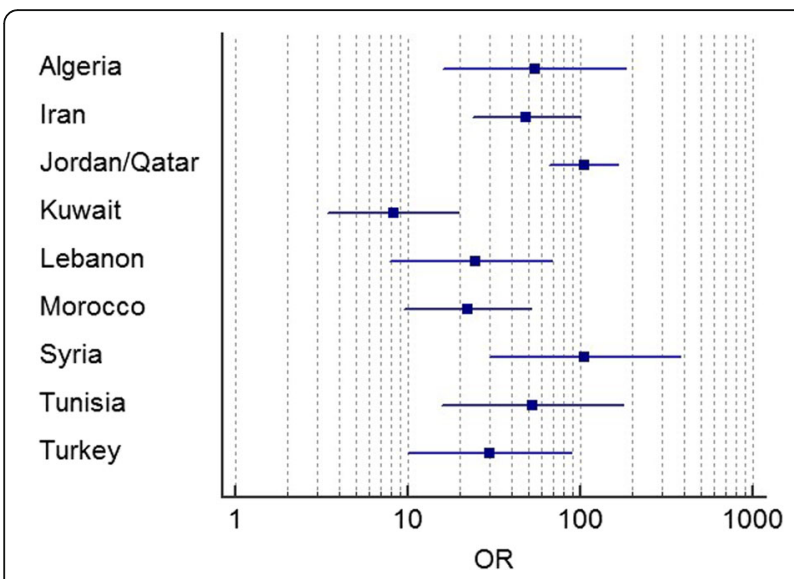

Fig. 1 Forest plot showing the available odds ratios by country (OR, in logarithmic scale) and their respective 95\% confidence intervals

homogeneous inclusion criteria (unique classification criteria, no mixing with other diseases or subtypes such as Behçet's diseases or coxitis) were found in only twothirds of the studies (14 out of 22). Most heterogeneity comes from the mixing of different types of SpA (SpA plus other forms diagnosed by ESSG criteria - which may include peripheral forms as well). The evaluation of the studies according to the pre-defined quality indicators is summarized in Table 2 .

\section{Discussion}

The prevalence of HLA-B27 in the normal population is significantly lower in the Middle Eastern and Arab countries $(0.3 \%$ to $6.8 \%)$ than rates reported in the United States and Europe (6\% to 25\%) [14-16]. Nonetheless, HLA-B27 seems to be correlated with AxSpA as reflected by high ORs (HLA-B27 in AxSpA compared to HLA-B27 in the normal population), and HLA-B27 testing can be useful for AxSpA diagnosis. However, the local data should be considered when adapting the published referral strategies, as those strategies were tested in countries with high HLA-B27 prevalence. Heterogeneity between Middle Eastern and Arab countries may be mostly due to methodological differences in the studies rather than to true differences between the populations.

Table 2 Evaluation of the studies according to the quality indicators

\begin{tabular}{cc}
\hline Quality Indicator & $\begin{array}{c}\text { Number of studies / } \\
\text { Total studies }\end{array}$ \\
\hline Sample size & $8 / 22$ \\
- AS $<30$ patients & 12 / 22 \\
- AS $>50$ patients & $11 / 27$ \\
Presence of control group & $3 / 27$ \\
Method of HLA-B27 testing stated & $14 / 22$ \\
\hline
\end{tabular}

The first heterogeneity is related to SpA samples: some studies have very low sample size (as low as 12 patients), leading to large CIs indicating poorly powered studies. Also, heterogeneity may result from differences in the classification criteria used: AxSpA diagnosis was based on different types of criteria (NY, Amor, ESSG). Amor and ESSG criteria based diagnoses may include nonaxial forms, which are known to be less associated with HLA-B27. The third heterogeneity is related to the control groups: absent in two-thirds of the studies, general rheumatology patients, blood donors. And finally, heterogeneity may be related to the method of HLA-B27 testing, which could not be assessed because it was often not described. Older testing methods may have been less sensitive.

\section{Conclusion}

Since HLA-B27 is now a key feature in the diagnosis of $\mathrm{SpA}$, the strength of its association with SpA in MiddleEastern and Arab countries should be addressed in high quality studies: sufficient sample size, adequate diagnosis of SpA according to the latest criteria, adequate control group and sensitive HLA-B27 testing methods. It would be interesting to evaluate the performance of the ASAS criteria in our specific population. Furthermore, identification of new diagnostic markers in these specific populations is warranted.

\section{Abbreviations}

AS: Ankylosing Spondylitis; AxSpA: Axial Spondyloarthritis; Cl: Confidence Interval; ESSG: European Spondyloarthropathy Study Group; NY: New York; OR: Odds Ratio; SpA: Spondyloarthritis

\section{Acknowledgements}

Not applicable.

Funding

No external source of funding available.

\section{Availability of data and materials}

Material described in the manuscript, including all relevant raw data, will be freely available to any scientist wishing to use them for non-commercial purposes.

\section{Author's contributions}

The single author is responsible for the whole manuscript. NRZ designed the study performed the literature search, analyzed the data and wrote the manuscript.

Ethics approval and consent to participate

Not applicable (no human participants, human data or human tissue included).

Consent for publication

Not applicable (no human individual data).

Competing interests

No financial and non-financial competing interests to declare.

\section{Publisher's note}

Springer Nature remains neutral with regard to jurisdictional claims in published maps and institutional affiliations. 


\section{Author details}

'Rheumatology Department, Saint-Joseph University, Beirut, Lebanon. ${ }^{2}$ Rheumatology Department, Hotel-Dieu de France Hospital, Beirut, Lebanon. ${ }^{3}$ Tour des Consultations Externes, Hotel-Dieu de France hospital, 6th floor, Alfred Naccache blvd, Achrafieh, PO BOX 166830, Beirut, Lebanon.

Received: 17 August 2016 Accepted: 21 June 2017

Published online: 29 June 2017

\section{References}

1. Poddubnyy D, Rudwaleit M. Early spondyloarthritis. Rheum Dis Clin N Am. 2012;38:387-403.

2. Boonen A, van der Linden S. The burden of ankylosing spondylitis. J Rheumatol. 2006:33:4-11.

3. Wendling D, Claudepierre P, Prati C. Early diagnosis and management are crucial in spondyloarthritis. Joint Bone Spine. 2013;80(6):582-5.

4. Van der Linden S, Valkenburg HA, Cats A. Evaluation of diagnostic criteria for ankylosing spondylitis. A proposal for modification of the New York criteria. Arthritis Rheum. 1984;27(4):361-8.

5. Amor B, Dougados M, Mijiyawa M. Criteria of the classification of spondylarthropathies. Rev Rhum Mal Osteoartic. 1990;57:85-9.

6. Dougados M, van der Linden S, Juhlin R, Huitfeldt B, Amor B, Calin A, et al. The European Spondylarthropathy study group preliminary criteria for the classification of spondylarthropathy. Arthritis Rheum. 1991;34:1218-27.

7. Rudwaleit M, Landewe R, van der Heijde D, Listing J, Brandt J, Braun J, et al. The development of assessment of SpondyloArthritis international Spciety classification criteria for axial spondyloarthritis (part 1): classification of paper patients by expert opinion including uncertainty appraisal. Ann Rheum Dis. 2009;68:770-6.

8. Rudwaleit M, van der Heidje D, Landewe R, Listing J, Akkoc N, Brandt J, et al. The development of assessment of SpondyloArthritis international Society classification criteria for axial spondyloarthritis (part II): validation and final selection. Ann Rheum Dis. 2009:68:777-83.

9. Rudwaleit M, Sieper J. Referral strategies for early diagnosis of axial spondyloarthritis. Nat Rev Rheumatol. 2012;8:262-8.

10. Sieper J, Rudwaleit M. Early referral recommendations for ankylosing spondylitis (including preradiographic and radiographic forms). Ann Rheum Dis. 2005;64:659-63.

11. Rachid B, El Zorkany B, Yousseif E, Tikly M. Early diagnosis and treatment of ankylosing spondylitis in Africa and the Middle East. Clin Rheumatol. 2012; 31:1633-9.

12. Mustafa K, Hammoudeh M, Khan MA. HLA-B27 prevalence in Arab populations and among patients with Ankylosing Spondylitis. J Rheumatol. 2012;39:1675-7.

13. Szumilas M. Explaining odds ratios. J Can Acad Child Adolesc Psychiatry. 2010;19:227-9.

14. Khan MA. HLA-B27 and its subtypes in world populations. Curr Opin Rheumatol. 1995;7:263-9.

15. Khan MA. HLA-B27 and its pathogenic role. J Clin Rheumatol. 2008:14:50-2.

16. Reveille JD, Hirsch R, Dillon CF, Carroll MD, Weisman MH. The prevalence of HLA-B27 in the US: data from the US national health and nutrition examination survey 2009. Arthritis Rheum. 2012;64:1407-11.

17. Amroun H, Djoudi H, Busson M, Allat R, El Sherbini SM, Sloma I, et al. Earlyonset ankylosing spondylitis is associated with a functional MICA polymorphism. Hum Immunol. 2005:66:1057-61.

18. Hafez M, El-Shennawy FA. HLA antigens in the Egyptian population. Forensic Sci Int. 1986;31:241-6.

19. Tayel M, Soliman E, EL Baz W, El Labaan A, Hamaad Y, Ahmed MH. Registry of the clinical characteristics of spondyloarthritis in a cohort of Egyptian population. Rheumatol Int. 2012;32:2837-42.

20. Donna AF, Ismail AM, Moustafa F-H. HLA class I typing in Egyptian childhood minimal change nephrotic syndrome. J Nephrol. 2008;21(5):734-7.

21. Al-Rawi ZS, Al-Shakarchi HA, Hasan F, Thewaini AJ. Ankylosing spondylitis and its association with the histocompatibility antigen HL-A B27: an epidemiological and clinical study. Rheumatol Rehabil. 1978;17:725.

22. Fouladi S, Adib M, Salehi M, Karimzadeh H, Bakhshiani Z, Ostadi V. Distribution of HLA-B27 allele in patients with Ankylosing Spondylitis in Iran. Iran J Immunol. 2009;6:49-54.

23. Nicknam MH, Mahmoudi M, Amirzargar A, Ganjalikhani Hakemi M, Khosravi F, Jamshidi AR, et al. Determintation of HLA-B27 subtypes in Iranian patients with ankylosaing spondylitis. Iran J Allergy Asthma Immunol. 2008;7(1):19-24.
24. Nazarinia MA, Ghaffarpasand F, Heiran HR, Habibagahi Z. Pattern of Ankylosing spondylitis in an Iranian population of 98 patients. Mod Rheumatol. 2009;19:309-15.

25. Brautbar C, Porat S, Nelken D, Gabriel KR, Cohen T. HLA B27 and ankylosing spondylitis in the Israeli population. J Rheumatol Suppl. 1977;3:24-32.

26. Askari A, AL Bdrour $M$, Saadeh A, Sawalha AH. Ankylosing Spondylitis in northern Jordan: descriptive and analytical study. Ann Rheum Dis. 2000; 59:571-3.

27. Uppal S, Abraham L, Chowdhury LI, Kumari R, Pathan EM, Al RA. Ankylosing spondylitis and undifferentiated spondyloarthritis in Kuwait: a comparison between Arabs and south Asians. Clin Rheum. 2006:25:219-24.

28. Alharbi SA, Mahmoud FF, Al Awadi A, Al Jumma RA, Khodakhast F, Alsulaiman SM. Association of MHC class I with spondyloarthropathies in Kuwait. Eur J Immunogenet. 1996;23:67-70.

29. Awada H, Baddoura R, Naman R, Klayme S, Mansour I, Tamouza R, et al. Weak association between HLA-B27 and spondylarthropathies in Lebanon. Arthritis Rheum. 1997:40:388-90.

30. Atouf O, Benbouazza K, Brick C, Saoud B, Benseffaj N, Amine B, et al. Distribution of HLA class I and II genes in ankylosing spondylitis patients from Morocco. Pathol Biol (Paris). 2012:60(6):e80-3.

31. Younsi R, Azrib S, Aitouazar M, Harifi G, El Hassani S. Evaluation de l'incidence du gène HLA-B27 chez le patient atteint de spondylarthrite ankylosante au Maroc. Rev Rhum. 2007;74:976-1037.

32. White AG, Leheny W, Kuchipudi $P$, Varghese $M$, Al Riyami $H$, Al Hashmi S, et al. Histocompatibility antigens in Omanis: comparison with other gulf populations and implication for disease association. Ann Saudi Med. 1999;19:193-6.

33. Abdelrahman MH, Mahdy S, Khanjar IA, Siam AM, Malallah HA, Al-Emadi SA, et al. Prevalence of HLA-B27 in patients with ankylosing spondylitis in Qatar. Int J Rheumatol. 2012;2012:860213.

34. Al-Arfaj A. Profile of ankylosing spondylitis in Saudi Arabia. Clin Rheumatol. 1996:15:287-9

35. Harfouch E, Al CS. HLA-B27 and its subtypes in Syrian patients with ankylosing spondylitis. Saudi Med J. 2011;32:364-8.

36. Sakly N, Boumiza R, Zrour-Hassen S, Hamzaoui A, Ben Yahia S, Amara H, et al. HLA-B27 and HLA-B51 determination in Tunisian healthy subjects and patients with suspected ankylosing spondylitis and Behçet's disease. Ann N Y Acad Sci. 2009:173:564-9.

37. Kchir MM, Hamdi W, Laadhar L, Kochbati S, Kaffel D, Saadellaoui K, et al. HLA-B, DR and DQ antigens polymorphism in Tunisian patients with ankylosing spondylitis (a case-control study). Rheumatol Int. 2010;30:933-9.

38. Younes M, Jalled A, Aydi Z, Zrour S, Korbaa W, Ben Salah Z, et al. Socioeconomic impact of ankylosing spondylitis in Tunisia. Joint Bone Spine. 2010;77:41-6.

39. Gunal E, Sarvan F, Kamali S, Gul A, Inanc M, Carin M, et al. Low frequency of HLA-B27 in ankylosing spondylitis patients from Turkey. Joint Bone Spine. 2009;75(3):299-302.

40. Bodur H, Ataman S, Akbulut L, Evcik D, Kavuncu V, Kaya T, et al. Characteristics and medical management of patients with rheumatoid arthritis and ankylosing spondylitis. Clin Rheumatol. 2008:27:1119-25.

41. Al Attiah HM, Sherif AM, Hossain MM, Ahmed YH. The demographic and clinical spectrum of Arab versus Asian patients with ankylosing spondylitis in the UAE. Rheumatol Int. 1998;17:193-6.

42. Al Attiah HM, Al AN. HLA-B27 in healthy adults in UAE. An extremely low prevalence in Emirian Arabs. Scand J Rheumatol. 1995;24:225-7.

\section{Submit your next manuscript to BioMed Central and we will help you at every step:}

- We accept pre-submission inquiries

- Our selector tool helps you to find the most relevant journal

- We provide round the clock customer support

- Convenient online submission

- Thorough peer review

- Inclusion in PubMed and all major indexing services

- Maximum visibility for your research

Submit your manuscript at www.biomedcentral.com/submit
C) Biomed Central 